\title{
Sources of Resistance to Fumonisin Accumulation in Grain and Fusarium Ear and Kernel Rot of Corn
}

\author{
M. J. Clements, C. M. Maragos, J. K. Pataky, and D. G. White
}

First, third, and fourth authors: Department of Crop Sciences, University of Illinois, Urbana 61801; and second author: U.S. Department of Agriculture-Agricultural Research Service (USDA-ARS) Mycotoxin Research Unit, Peoria, IL 61604.

Current address of the M. J. Clements: USDA-ARS Corn Host Plant Resistance Research Unit, Mississippi State, MS 39762.

Accepted for publication 7 October 2003.

\begin{abstract}
Clements, M. J., Maragos, C. M., Pataky, J. K., and White, D. G. 2004. Sources of resistance to fumonisin accumulation in grain and Fusarium ear and kernel rot of corn. Phytopathology 94:251-260.

Fumonisin is a group of homologous mycotoxins produced by several species of Fusarium. Fumonisin has been associated with Fusarium ear and kernel rot of corn (Zea mays) and several toxicoses of animals and humans. Corn inbreds with a high level of resistance to fumonisin production and accumulation in grain have not been identified. The objective of this study was to evaluate a genetically diverse collection of inbreds as potential sources of resistance to fumonisin production and accumulation in grain and Fusarium ear and kernel rot when crossed with a commercial "B73-type" line. $\mathrm{F}_{1}$ hybrids developed with the inbred FR1064 and 1,589
\end{abstract}

ABSTRACT

A group of homologous mycotoxins known as fumonisin is produced by several species of Fusarium Link. Fumonisin is synthesized in corn (Zea mays L.) grain by Fusarium verticillioides (Sacc.) Nirenberg (Syn. $=F$. moniliforme J. Sheld.) and $F$. proliferatum (Matsushima) Nirenberg. These two species cause Fusarium ear and kernel rot of corn. Fumonisin is a causal agent of several toxicoses of animals (7) and is implicated as a contributing factor to outbreaks of esophageal cancer $(9,11,16,39,47)$ and neural tube birth defects (45) in humans.

The U.S. Food and Drug Administration recommends that cleaned and dry milled corn destined for human consumption contain no more than 2 to $4 \mu \mathrm{g}$ of fumonisin (total of homologues $\mathrm{FB}_{1}, \mathrm{FB}_{2}$, and $\left.\mathrm{FB}_{3}\right)$ per gram $(7,8)$. A substantial portion of the corn crop in the United States could have a fumonisin concentration in grain that is above this guideline when environmental conditions favor disease development. Fumonisin concentration in corn grain produced in the midwestern United States is frequently between 0 to $5 \mu \mathrm{g} / \mathrm{g}(1,30,32,40,53)$. Concentrations above $5 \mu \mathrm{g} / \mathrm{g}$ are common in some years. Although fumonisin concentration in grain and severity of Fusarium ear and kernel rot are moderately correlated (13), fumonisin has been detected at levels of concern from asymptomatic corn kernels $(4,11,35,39)$.

Corresponding author: M. J. Clements; E-mail address: mclements@ars.usda.gov

Conclusions, opinions, and recommendations expressed in this publication are those of the authors and do not necessarily reflect the views of CFAR or the NRI. Mention of a trade name or proprietary product does not constitute endorsement by the U.S. Department of Agriculture, University of Illinois, or Mississippi State University.

Publication no. P-2003-1229-01R

This article is in the public domain and not copyrightable. It may be freely reprinted with customary crediting of the source. The American Phytopathological Society, 2004. and 1,030 inbreds were evaluated in inoculated and naturally infected trials, respectively, in 2000. Thirty-five $\mathrm{F}_{1}$ hybrids with fumonisin concentration in grain of $\leq 5 \mu \mathrm{g} / \mathrm{g}$ in both trials were selected. Inbreds from which these $35 \mathrm{~F}_{1}$ hybrids were produced included yellow-, white-, and red-kernelled lines; flint and dent lines; and early- through late-maturing lines. In 2001, low fumonisin concentration in grain and low ear rot severity were associated with several of the $F_{1}$ hybrids and their distinct $\mathrm{F}_{2}$, and backcross to FR1064 generations. This suggests that several dominant genes are involved in resistance and that alleles for resistance from these inbreds can be transferred to FR1064.

Additional keywords: F. moniliforme, F. verticillioides, Gibberella fujikuroi, maize.

Potential problems resulting from fumonisin in feed and food may be minimized by proactive breeding programs aimed at reducing fumonisin concentration in corn grain.

Several studies have examined resistance to Fusarium ear and kernel rot and the mechanisms associated with infection. King and Scott $(24,41)$ reported that incidence of kernels infected with Fusarium sp. is under genetic control. Additive gene effects from the inbred Mp420 (3) and additive and dominant gene effects from the sweet corn inbred IL125b (33) have been associated with resistance to Fusarium ear and kernel rot. Boling and Grogan (3) estimated that very few gene pairs (approximately one) are involved in resistance to Fusarium ear and kernel rot. Nankam and Pataky (33) estimated that 3 to 12 effective factors are associated with resistance to kernel infection by $F$. verticillioides. Broadsense heritability was estimated to be between 0.24 and 0.46 for asymptomatic infection, and between 0.32 and 0.55 for symptomatic infection. Resistance to kernel infection by $F$. verticillioides was dominant in sources of resistance evaluated in two other studies $(20,41)$.

Local infection of kernels is the most important pathway of infection for Fusarium ear and kernel rot $(14,22,27,31,41)$, although systemic movement of $F$. verticillioides from infected seed (31) and stalks (15) to developing corn kernels has been reported. Local infection of kernels by $F$. verticillioides often is the result of airborne conidia that germinate on corn silks $(22,27,37,41,54)$. Local infection and the development of Fusarium ear and kernel rot also have been associated with feeding damage from several insect species $(10,14,17,27,42,44,52)$. Infection of kernels by airborne conidia or by conidia vectored by insects is exacerbated by incomplete or loose coverage of kernels by the husk leaves $(2,22$, $27,41,50)$, early silk senescence $(14,20-22)$, and kernel splitting (36).

Mechanisms of resistance to local infection of corn kernels by Fusarium spp. are not fully understood; however, resistance to 
local infection has been associated with the silks $(20,21,41,51)$, pericarp $(20,23,41)$, aleurone layer $(23)$, pedicel $(22,54)$, and placento-chalazal region, i.e., black layer (20), of corn kernels. Resistance to local infection is not generally associated with the endosperm, embryo, or cytoplasm $(20,21,41)$. However, severe ear rot and/or high incidence of kernel infection have been reported for high-lysine (opaque-2) inbreds (51) and inbreds with shrunken-2 (sh2) endosperm (46).

Although a number of inbreds with resistance to kernel infection by $F$. verticillioides or to Fusarium ear and kernel rot have been identified $(20,24,41,43,51)$, inbreds with a high level of resistance to the production or accumulation of fumonisin in grain have not been identified. Because fumonisins were identified only recently, resistance to accumulation of these mycotoxins in grain was not evaluated in most of the previous studies of Fusarium ear and kernel rot. Our objective was to evaluate a large, genetically diverse collection of inbred lines as potential sources of resistance to fumonisin accumulation in grain and Fusarium ear and kernel rot of corn.

\section{MATERIALS AND METHODS}

Preliminary evaluation. A genetically diverse collection of 1,589 inbred lines was screened for resistance to fumonisin accumulation in grain and severity of Fusarium ear and kernel rot when crossed with a susceptible, widely used commercial "B73type" line (48). Inbreds that contribute resistance to $F_{1}$ crosses with B73-type lines will be useful for the improvement of hybrids grown throughout the United States. Inbreds were crossed with FR1064 (pollen parent) in 1999 to produce $F_{1}$ seed. FR1064 is a widely used, proprietary, B73-type inbred developed by Illinois Foundation Seeds (Champaign, IL) (18). Seed of 1,589 $\mathrm{F}_{1}$ hybrids was planted on 25 April 2000 at the Crop Science Research and Education Center, Urbana, IL. The experimental design was a randomized complete block with two replicates. Experimental units were single rows that were $5.3 \mathrm{~m}$ in length, spaced $0.8 \mathrm{~m}$ apart, with approximately 24 plants per row. Two replicates of 1,223 of the $F_{1}$ hybrids were planted on 7 and 10 April 2000 in plots provided by Syngenta (Basal, Switzerland) in eastern North Carolina. One replicate was at Winterville, and one replicate was at Ponzer. Plots at Winterville and Ponzer were considered one trial because weather conditions were similar in these regions in 2000, and effects of our inoculation treatments were confounded with location. Poor emergence and poor stands further reduced the number of hybrids at the North Carolina trial to 1,030 .

Incidence and severity of Fusarium ear and kernel rot typically are high in eastern North Carolina; therefore, plants were not inoculated in this trial. In Illinois, $10 \mathrm{ml}$ of a propagule suspension was injected down the silk channel of all primary ears at the R1 (silking) growth stage and through the husk leaves of the same ears at the R2 (blister) growth stage.

Inoculum was produced from one isolate of $F$. verticillioides (number 150) and four isolates of $F$. proliferatum (numbers 19 , $37-2,42$, and 310 ) that differed in their capacity to induce symptoms of Fusarium ear and kernel rot and synthesize fumonisin in grain when corn ears were inoculated with individual isolates in another study (12). One isolate of $F$. verticillioides, number 152 , that does not produce fumonisin in grain in field conditions (12; A. E. Desjardins, M. J. Clements, and D. G. White, unpublished data) also was used. Isolate 42 of $F$. proliferatum was identified as $F$. verticillioides in previous research $(12,13,25)$. Commercial corn hybrids that are susceptible or resistant to Fusarium ear and kernel rot and fumonisin accumulation have been differentiated successfully in studies in which a blend of all six isolates was injected into corn ears $(12,13,41)$. All isolates were maintained at the University of Illinois. Isolates were grown on potato dextrose agar (Becton Dickinson and Company, Sparks, MD) at approxi- mately $25^{\circ} \mathrm{C}$ under $12 \mathrm{~h}$ of diurnal fluorescent light for 7 to 14 days.

Inoculum was prepared by blending an equal number of cultures of the six isolates in de-ionized water. The resulting propagule suspension was strained through two layers of cheesecloth, diluted with water to a concentration of $10^{6}$ conidia per $\mathrm{ml}$ as determined with a hemacytometer, and amended with $0.2 \mathrm{ml}$ of Tween 20 surfactant per liter (polyoxyethylene 20-sorbitan monolaurate; Fisher Biotech, Fairlawn, NJ).

Inoculum was delivered with backpack sprayers (Model 425; Solo Inc., Newport News, VA) equipped with an injection device consisting of a Tee-Jet brand meter jet (Model 23623-31; Spraying Systems Co., Wheaton, IL) fitted with a $0.64-\mathrm{cm}$ Tee-Jet outlet adapter (Model 4676). A grease needle (Model 5803; Lincoln Automotive, St. Louis) with the orifice enlarged to $1.6 \mathrm{~mm}$ was attached to the Tee-Jet assembly to inoculate ears in the silk channel. A hollow stainless steel needle $(2.4$ by $0.2 \mathrm{~cm}$ ) (University of Illinois Civil and Environmental Engineering Machine Shop, Urbana) was attached to the Tee-Jet assembly to inoculate ears through the husk leaves.

Primary ears from all plants in all trials were harvested at approximately $18 \%$ grain moisture, dried with forced air at $32^{\circ} \mathrm{C}$ to approximately $14 \%$ grain moisture, and visually rated for severity of Fusarium ear and kernel rot as the percentage ( 0 to $100 \%)$ of the ear with symptoms. Ratings were estimated in increments of $5 \%$. Grain was shelled from cobs, bulked by experimental unit, and ground with a grinding/subsampling mill (Model 2A; Romer Labs, Inc., Union, MO) to pass through 1-mm mesh. A 25-g sample of ground corn from each experimental unit was analyzed for fumonisin concentration (total of $\mathrm{FB}_{1}, \mathrm{FB}_{2}$, and $\mathrm{FB}_{3}$ ) with a competitive-direct enzyme-linked immunosorbent assay described previously (13). Concentration of fumonisin in grain was determined by comparison of sample absorbance to a standard curve established with eight standards (equivalent to $0,0.1,0.45,1.0$, $4.5,10,45$, and $100 \mu \mathrm{g} / \mathrm{g}$ in sample extract) on each plate. Extract from grain samples with fumonisin concentration in excess of the standard curve was diluted in $0.01 \mathrm{M}$ phosphate-buffered saline and reanalyzed.

The effects of trials, $\mathrm{F}_{1}$ hybrids, and the interaction of these factors on fumonisin concentration in grain and severity of Fusarium ear and kernel rot were analyzed using the general linear model (GLM) procedure of Statistical Analysis System (SAS) software (SAS Institute, Cary, NC). Fumonisin concentration and severity of Fusarium ear and kernel rot were transformed to the natural $\log (1+\mu \mathrm{g}$ of fumonisin per $\mathrm{g}$ of ground corn) and the natural $\log (1+$ percent of the ear with symptoms $)$, respectively, to normalize residuals. Trials and replicates were considered random terms in the model and $\mathrm{F}_{1}$ hybrids were considered fixed. Pearson's correlation coefficients for fumonisin and ear rot were calculated from nontransformed treatment means. Weather information for central Illinois and eastern North Carolina was obtained from the Midwest Regional Climate Center, Champaign, IL, and the Southeast Regional Climate Center, Columbia, SC, respectively.

Advanced evaluation. Thirty-five $F_{1}$ hybrids were selected for a low concentration of fumonisin in grain and a low severity of Fusarium ear and kernel rot based on the evaluation in 2000. Concurrent with these evaluations, seed of the $F_{2}$ and the backcross to the susceptible parent $\left(\mathrm{BCP}_{2}\right)$ generations was produced by selfpollinating $F_{1}$ plants and by crossing $F_{1}$ plants with FR1064 as the pollen parent, respectively. Seed of the $35 \mathrm{~F}_{1}$ hybrids, both parental lines $\left(\mathrm{P}_{1}\right.$ and $\left.\mathrm{P}_{2}\right)$, the $\mathrm{F}_{2}$ generation, and the $\mathrm{BCP}_{2}$ generation were planted 27 April 2001 at Urbana, IL. Seed of $29 \mathrm{~F}_{1}$ hybrids and their parental, $\mathrm{F}_{2}$ and $\mathrm{BCP}_{2}$ generations were planted 1 May 2001 at Haubstadt, IN, in plots provided by Monsanto. Experimental units consisted of one row of each parental line $\left(\mathrm{P}_{1}\right.$ and $\mathrm{P}_{2}$ ), one row of the $\mathrm{F}_{1}$ hybrid, and two rows each of the $\mathrm{F}_{2}$ and $\mathrm{BCP}_{2}$ generations. Rows were $5.3 \mathrm{~m}$ in length, spaced $0.8 \mathrm{~m}$ 
apart, and included 20 to 24 plants. The experimental design was a randomized complete block arranged as a split plot with three replicates per location. Progeny groups (all generations associated with a selected inbred line, $\mathrm{P}_{1}$ ) were main plots. Four generations $\left(\mathrm{P}_{1}, \mathrm{~F}_{1}, \mathrm{~F}_{2}\right.$, and $\left.\mathrm{BCP}_{2}\right)$ were randomized within main plots as subplots. FR1064 $\left(\mathrm{P}_{2}\right)$ was randomized with the four generations within main plots for comparison. The treatment design was a $35 \times 4$ factorial or a $29 \times 4$ factorial of 35 or 29 progeny groups and four generations.

Primary ears on all plants were inoculated twice, harvested, dried, and visually rated for severity of Fusarium ear and kernel rot as described for the preliminary evaluation in 2000. Grain was shelled from cobs, ground, and analyzed for fumonisin concentration as in 2000.

Effects of locations, progeny groups, generations, and the interactions of these factors on fumonisin concentration in grain and severity of Fusarium ear and kernel rot were analyzed with the GLM procedure of SAS. Fumonisin concentration and severity of Fusarium ear and kernel rot were transformed as in 2000 to normalize residuals. Locations and replicates were considered random terms in the analyses, and progeny groups and generations were considered fixed. Differences between progeny groups and generations were compared with Fisher's protected least significant difference test (LSD) (38). Generation was compared to likegeneration across progeny groups with Fisher's LSD test. Variances were compared between segregating generations $\left(\mathrm{F}_{2}\right.$ and $\left.\mathrm{BCP}_{2}\right)$ and nonsegregating generations $\left(\mathrm{P}_{1}, \mathrm{P}_{2}\right.$, and $\left.\mathrm{F}_{1}\right)$ with Hartley's test for homogeneity of population variances (38) to determine if a large or small number of genes may be involved in resistance. Weather information for central Illinois and southwestern Indiana was obtained from the Midwest Regional Climate Center, Champaign, IL, and the University of Kentucky Agricultural Weather Center, Lexington, respectively.

\section{RESULTS}

Preliminary evaluation. Temperature was near average in central Illinois $\left(30\right.$ year mean $=22.9^{\circ} \mathrm{C}$ ) and eastern North Carolina (30 year mean $=26.0^{\circ} \mathrm{C}$ ) during June, July, and August of 2000 . Precipitation was $6.9 \mathrm{~cm}$ below the sum of the 30 year means for June, July, and August (sum of 30 year means $=33.7 \mathrm{~cm}$ ) in central Illinois in 2000. Precipitation was $11.9 \mathrm{~cm}$ above the sum of the 30 year means for June, July, and August (sum of 30 year means $=41.5 \mathrm{~cm}$ ) in eastern North Carolina in 2000. Precipitation was generally greatest after pollination in central Illinois and eastern North Carolina.

Treatment means for fumonisin concentration in grain ranged from 2 to $482 \mu \mathrm{g} / \mathrm{g}$ in Illinois with a grand mean of $23 \mu \mathrm{g} / \mathrm{g}$, and from 1 to $130 \mu \mathrm{g} / \mathrm{g}$ in North Carolina with a grand mean of $14 \mu \mathrm{g} / \mathrm{g}$. Fumonisin concentration was affected significantly by trials, hybrids, and the trial-hybrid interaction $(P<0.0001)$. Fumonisin concentration was less than or equal to $5 \mu \mathrm{g} / \mathrm{g}$ for 189 hybrids in Illinois and 145 hybrids in North Carolina, but for only 12 hybrids in both trials (A188, A682, B8, B66, C127, CK31, CM5, CQ201, H117, M14, and ND211) (Fig. 1; Table 1).

Severity of Fusarium ear and kernel rot was affected significantly by trials, hybrids, and the trial-hybrid interaction $(P<$ $0.0001)$. Treatment means for ear rot severity ranged from 0 to $59 \%$ in Illinois with a grand mean of $8 \%$, and from 0 to $33 \%$ in North Carolina with a grand mean of $5 \%$. Severity of Fusarium ear and kernel rot was less than or equal to $5 \%$ for 806 hybrids in Illinois and 670 hybrids in North Carolina, but for only 344 hybrids in both trials (Fig. 2).

Pearson's correlation coefficients for fumonisin concentration in grain and ear rot severity were $r=0.54(P<0.0001)$ and $r=$ $0.60(P<0.0001)$ for trials in Illinois and North Carolina, respectively. Correlation coefficients for fumonisin concentration and for ear rot severity between trials were not significant $(P=$
0.3722 and 0.7518 , respectively). Severity of Fusarium ear and kernel rot was less than or equal to $5 \%$ and fumonisin concentration was greater than $5 \mu \mathrm{g} / \mathrm{g}$ for 615 hybrids in Illinois and 500 hybrids in North Carolina. Fumonisin concentration was greater than $20 \mu \mathrm{g} / \mathrm{g}$ for 92 and 42 of these hybrids in Illinois and North Carolina, respectively.

Thirty-five hybrids were selected for further study based on low fumonisin concentration in grain and low severity of $\mathrm{Fu}$ sarium ear and kernel rot in the preliminary evaluation (Table 1). Fumonisin concentration from each of these hybrids averaged less than or equal to $5 \mu \mathrm{g} / \mathrm{g}$ across both trials or less than or equal to $4 \mu \mathrm{g} / \mathrm{g}$ when data from only one trial was available.

Advanced evaluation. Temperature was near average in central Illinois $\left(30\right.$ year mean $\left.=22.9^{\circ} \mathrm{C}\right)$ and southwestern Indiana (30 year mean $=23.9^{\circ} \mathrm{C}$ ) during June, July, and August of 2001 . Precipitation was $5.1 \mathrm{~cm}$ below the sum of the 30 year means for June, July, and August (sum of 30 year means $=33.7 \mathrm{~cm}$ ) in central Illinois in 2001. Precipitation was $5.5 \mathrm{~cm}$ above the sum of the 30 year means for June, July, and August (sum of 30 year means $=31.5 \mathrm{~cm}$ ) in southwestern Indiana in 2001. Precipitation was generally greatest after pollination at both locations.

Treatment means for fumonisin concentration in grain ranged from 2 to $106 \mu \mathrm{g} / \mathrm{g}$ with a grand mean of $18 \mu \mathrm{g} / \mathrm{g}$ in Illinois, and from 2 to $107 \mu \mathrm{g} / \mathrm{g}$ with a grand mean of $18 \mu \mathrm{g} / \mathrm{g}$ in Indiana. Fumonisin concentration averaged $94 \mu \mathrm{g} / \mathrm{g}$ across locations for susceptible inbred FR1064. Fumonisin concentration was affected significantly by the progeny group, location-progeny group, location-generation, and progeny group-generation interactions $(P=0.0121, P=0.0009, P<0.0001$, and $P<0.0001$, respectively). Fumonisin concentration was not affected significantly by locations, generations $\left(\mathrm{P}_{1}, \mathrm{~F}_{1}, \mathrm{~F}_{2}, \mathrm{BCP}_{2}\right)$, or the location-progeny group-generation interaction $(P=0.6990, P=0.0736$, and $P=$ 0.0812 , respectively).

Fumonisin concentration in grain was lowest in Illinois for the progeny group developed from inbred CG1 (progeny group mean = $4 \mu \mathrm{g} / \mathrm{g}$ ) and in Indiana for the progeny group developed from inbred L289 (progeny group mean $=5 \mu \mathrm{g} / \mathrm{g}$ ) (Table 2). Fumonisin concentration was not significantly different between progeny group CG1 and three other groups in Illinois (CM5, CQ201, and TBA76125) or between progeny group L289 and seven other groups in Indiana (B8, CQ201, GE440, SDp2A, SP228, TBA76125, and W438). At both locations, progeny groups CQ201 and TBA76125 were among those associated with the lowest fumonisin concentration in grain (Table 2).

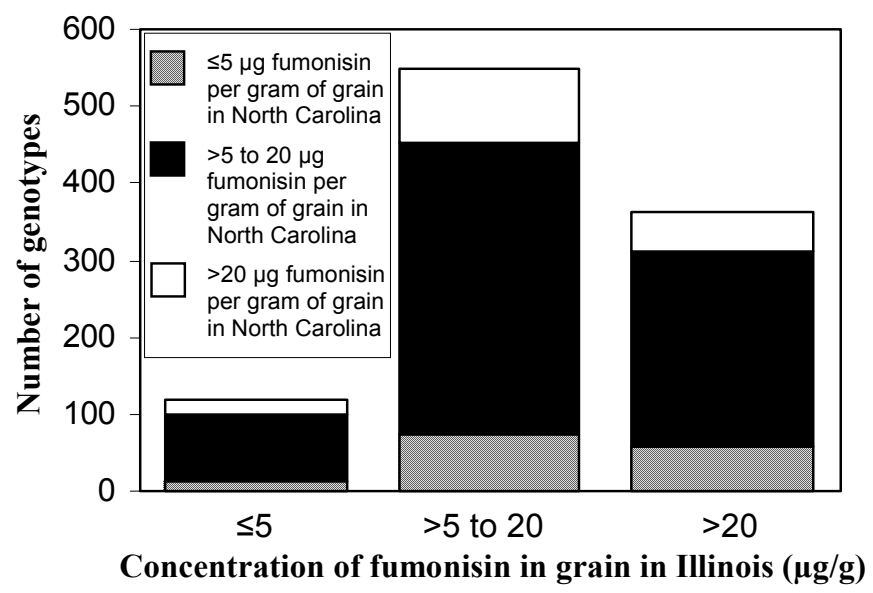

Fig. 1. Concentration of fumonisin in grain of 1,030 hybrids evaluated in inoculated trials in Illinois and noninoculated trials in North Carolina in 2000. Categories of fumonisin represent approximate safe levels established by the U.S. Food and Drug Administration for humans and equines, swine, and other livestock, respectively, in the Guidance for Industry for corn and corn products (8). 
Fumonisin concentration in grain averaged across progeny groups was significantly lower for the $F_{1}$ generation than for the $\mathrm{P}_{1}, \mathrm{~F}_{2}$, and $\mathrm{BCP}_{2}$ generations in Illinois and Indiana (Table 3). Fumonisin concentration averaged 6 and $9 \mu \mathrm{g} / \mathrm{g}$ across all progeny groups for the $F_{1}$ generation in Illinois and Indiana, respectively. Fumonisin concentration was greatest for the average of $\mathrm{BCP}_{2}$ generation across all progeny groups in Illinois (mean $=25 \mu \mathrm{g} / \mathrm{g}$ ) and greatest for the average of $\mathrm{F}_{2}$ and $\mathrm{BCP}_{2}$ generations across all progeny groups in Indiana (means $=15$ and $16 \mu \mathrm{g} / \mathrm{g}$, respectively).

Fumonisin concentration in grain was significantly different among progeny groups within the $\mathrm{P}_{1}, \mathrm{~F}_{1}, \mathrm{~F}_{2}$, and $\mathrm{BCP}_{2}$ generations $(P<0.0001, P<0.0001, P<0.0001$, and $P<0.0001$, respectively). Fumonisin concentration was lowest for the $\mathrm{P}_{1}, \mathrm{~F}_{1}, \mathrm{~F}_{2}$, and $\mathrm{BCP}_{2}$ generations from progeny group CG1 (Table 2). Inbreds from 13 progeny groups, $\mathrm{F}_{1}$ hybrids from 18 progeny groups, $\mathrm{F}_{2}$ generations from 15 progeny groups, and $\mathrm{BCP}_{2}$ generations from 18 progeny groups had fumonisin concentration that was not significantly different from the respective generations of progeny group CG1. All generations of progeny groups B8, Sp228, CQ201, and TBA76125 had a fumonisin concentration that was not significantly different than the fumonisin concentration from corresponding generations of progeny group CG1 (Table 2). Three generations of progeny groups A188, B66, NY302, SQ18, Va46, Ge440, L289, and W438 had fumonisin concentration that was not significantly different from the corresponding generations of progeny group CG1.

Fumonisin concentration in grain was significantly different between 30 of the selected inbreds and FR1064 and 12 of the selected inbreds and their $\mathrm{F}_{1}$ hybrids with FR1064 (Table 2). Twenty of the selected inbreds had fumonisin concentration in grain that was not significantly different from their $F_{1}$ hybrids with FR1064. Fumonisin concentration was 55 to $92 \mu \mathrm{g} / \mathrm{g}$ lower in grain from 30 of the selected inbreds than from FR1064 when differences between treatment means were averaged over locations. Fumonisin concentration was 3 to $12 \mu \mathrm{g} / \mathrm{g}$ lower in grain

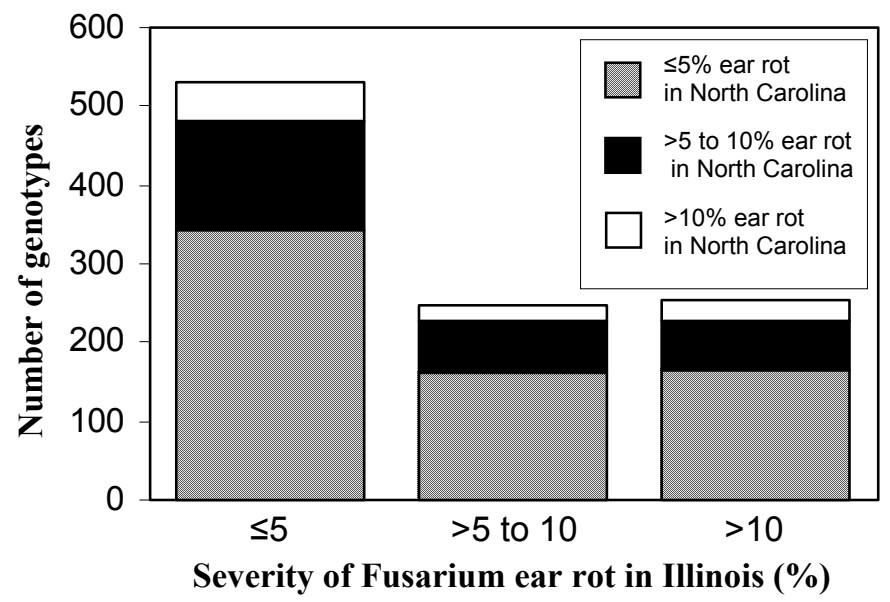

Fig. 2. Severity of Fusarium ear and kernel rot for 1,030 hybrids evaluated in inoculated trials in Illinois and noninoculated trials in North Carolina in 2000.

TABLE 1. $\mathrm{F}_{1}$ corn hybrids selected on the basis of low fumonisin concentration in grain and low severity of Fusarium ear and kernel rot from trials in Illinois and North Carolina in 2000

\begin{tabular}{|c|c|c|c|c|c|}
\hline \multirow[b]{2}{*}{$\mathrm{F}_{1}$ hybrid $^{\mathrm{a}}$} & \multirow{2}{*}{$\begin{array}{c}\text { Seed parent } \\
\text { endosperm type }\end{array}$} & \multicolumn{2}{|c|}{ Illinois } & \multicolumn{2}{|c|}{ North Carolina ${ }^{b}$} \\
\hline & & Fumonisin $(\mu \mathrm{g} / \mathrm{g})$ & Fusarium ear rot (\%) & Fumonisin $(\mu \mathrm{g} / \mathrm{g})$ & Fusarium ear rot $(\%)$ \\
\hline A131 × FR1064 & Yellow & 3 & 1 & 6 & 2 \\
\hline A635Rpld $\times$ FR 1064 & Yellow & 3 & 1 & 6 & 3 \\
\hline $\mathrm{B} 8 \times \mathrm{FR} 1064$ & Yellow & 3 & 1 & 5 & 2 \\
\hline B66 × FR1064 & Red & 3 & 1 & 4 & 2 \\
\hline BC555 × FR1064 & Yellow & 4 & 3 & 4 & 2 \\
\hline CM5 × FR1064 & Yellow & 3 & 2 & 5 & 1 \\
\hline CQ201 × FR1064 & Yellow & 3 & 1 & 4 & 2 \\
\hline FR36 × FR1064 & Yellow & 4 & 1 & 5 & 1 \\
\hline FR2114 × FR1064 & Yellow & 3 & 10 & 4 & 2 \\
\hline GE440 × FR1064 & White & 3 & 0 & $\ldots$ & $\ldots$ \\
\hline $\mathrm{H} 117 \times \mathrm{FR} 1064$ & Yellow & 4 & 0 & 1 & 2 \\
\hline $\mathrm{J} 2705 \mathrm{TV} \times \mathrm{FR} 1064$ & Yellow & 3 & 1 & $\ldots$ & $\ldots$ \\
\hline L289 × FR 1064 & Yellow & 3 & 3 & $\ldots$ & $\ldots$ \\
\hline M14 × FR1064 & Yellow & 4 & 1 & 5 & 1 \\
\hline M162W × FR1064 & White & 3 & 1 & $\ldots$ & $\ldots$ \\
\hline MI925 × FR1064 & Yellow & 5 & 2 & 3 & 1 \\
\hline ND302 × FR1064 & Yellow & 4 & 1 & 6 & 2 \\
\hline RN28Htrhm $\times$ FR1064 & Yellow & 3 & 2 & $\ldots$ & $\ldots$ \\
\hline $\mathrm{SDp} 2 \mathrm{~A} \times \mathrm{FR} 1064$ & Yellow & 3 & 3 & $\ldots$ & $\ldots$ \\
\hline SP228 × FR1064 & Yellow & 3 & 2 & $\ldots$ & $\ldots$ \\
\hline SQ18 × FR1064 & Yellow & 3 & 1 & $\ldots$ & $\ldots$ \\
\hline SU80-1 × FR1064 & Yellow & 4 & 0 & $\ldots$ & $\ldots$ \\
\hline TBA76125 × FR1064 & Yellow & 3 & 1 & $\ldots$ & $\ldots$ \\
\hline TIE84 × FR1064 & Yellow & 3 & 1 & $\ldots$ & $\ldots$ \\
\hline $\operatorname{TrTrf} \times$ FR1064 & Yellow & 3 & 1 & $\ldots$ & $\ldots$ \\
\hline Va46 × FR1064 & Yellow & 4 & 4 & $\ldots$ & $\ldots$ \\
\hline W438 × FR1064 & Yellow & 3 & 1 & $\ldots$ & $\ldots$ \\
\hline W627C $\times$ FR1064 & Yellow & 3 & 1 & $\ldots$ & $\ldots$ \\
\hline Y5 × FR1064 & Red & 3 & 1 & $\ldots$ & $\ldots$ \\
\hline A $188 \times$ FR 1064 & White & 5 & 2 & 5 & 2 \\
\hline CG1 × FR1064 & Yellow & 3 & 2 & 6 & 2 \\
\hline CK31 × FR1064 & Yellow & 4 & 0 & 3 & 1 \\
\hline NY302 × FR1064 & Yellow & 3 & 11 & $\ldots$ & $\ldots$ \\
\hline T236 × FR1064 & Yellow & 3 & 1 & $\ldots$ & $\ldots$ \\
\hline Va24 × FR1064 & Yellow & 3 & 7 & $\ldots$ & $\ldots$ \\
\hline
\end{tabular}

a FR1064 was the pollen parent in crosses.

b ... Indicates not evaluated due to poor emergence or lack of field space. 
TABLE 2. Concentration of fumonisin in grain of the $\mathrm{P}_{1}, \mathrm{P}_{2}, \mathrm{~F}_{1}, \mathrm{~F}_{2}$, and $\mathrm{BCP}_{2}$ generations associated with 35 progeny groups evaluated in $2001^{\mathrm{a}}$

\begin{tabular}{|c|c|c|c|c|c|c|c|c|c|c|c|c|c|c|c|}
\hline \multirow[b]{3}{*}{ Inbred } & \multicolumn{8}{|c|}{ Natural $\log$ of the concentration of fumonisin in grain ${ }^{\mathrm{b}}$} & \multicolumn{7}{|c|}{ Antilogarithm ( $\mu \mathrm{g}$ of fumonisin per gram of ground $\left.\operatorname{corn}^{\mathrm{c}}\right)$} \\
\hline & \multicolumn{2}{|c|}{$\begin{array}{l}\text { Average of progeny } \\
\text { group within location }\end{array}$} & \multicolumn{6}{|c|}{$\begin{array}{l}\text { Average of generation } \\
\text { across two locations }\end{array}$} & \multicolumn{2}{|c|}{$\begin{array}{l}\text { Average of progeny } \\
\text { group within location }\end{array}$} & \multicolumn{5}{|c|}{$\begin{array}{l}\text { Average of generation } \\
\text { across two locations }\end{array}$} \\
\hline & Illinois & Indiana & $\mathrm{P}_{1}$ & $\mathrm{P}_{2}$ & $\mathrm{~F}_{1}$ & $\mathrm{~F}_{2}$ & $\mathrm{BCP}_{2}$ & $\operatorname{LSD}_{\alpha=0.05^{\mathrm{d}}}$ & Illinois & Indiana & $\mathrm{P}_{1}$ & $\mathrm{P}_{2}$ & $\mathrm{~F}_{1}$ & $\mathrm{~F}_{2}$ & $\mathrm{BCP}_{2}$ \\
\hline A131 & 2.17 & 2.80 & 1.76 & 4.55 & 2.63 & 3.03 & 2.52 & 0.64 & 8 & 15 & 5 & 94 & 13 & 20 & 11 \\
\hline A635rpld & 2.54 & 2.83 & 2.25 & 4.55 & 2.21 & 2.81 & 3.48 & 0.78 & 12 & 16 & 9 & 94 & 8 & 16 & 31 \\
\hline B8 & 1.97 & 1.96 & 1.52 & 4.55 & 1.89 & 1.84 & 2.62 & 0.91 & 6 & 6 & 4 & 94 & 6 & 5 & 13 \\
\hline B66 & 2.02 & 2.80 & 2.26 & 4.55 & 1.82 & 2.52 & 3.03 & 0.74 & 7 & 15 & 9 & 94 & 5 & 11 & 20 \\
\hline CQ201 & 1.82 & 2.00 & 1.76 & 4.55 & 1.54 & 1.84 & 2.49 & 0.56 & 5 & 6 & 5 & 94 & 4 & 5 & 11 \\
\hline FR36 & 2.92 & 3.26 & 4.21 & 4.55 & 2.15 & 2.99 & 3.01 & 0.48 & 18 & 25 & 66 & 94 & 8 & 19 & 19 \\
\hline FR2114 & 2.92 & 2.67 & 1.98 & 4.55 & 2.27 & 3.25 & 3.70 & 0.55 & 18 & 13 & 6 & 94 & 9 & 25 & 39 \\
\hline GE440 & 2.51 & 2.13 & 1.80 & 4.55 & 1.44 & 2.38 & 3.29 & 0.69 & 11 & 7 & 5 & 94 & 3 & 10 & 26 \\
\hline H117 & 2.41 & 2.68 & 2.93 & 4.55 & 1.62 & 2.38 & 3.25 & 0.63 & 10 & 14 & 18 & 94 & 4 & 10 & 25 \\
\hline $\mathrm{J} 2705 \mathrm{TV}$ & 2.57 & 2.48 & & 4.55 & 1.90 & 2.68 & 3.00 & 0.40 & 12 & 11 & $\ldots$ & 94 & 6 & 14 & 19 \\
\hline L289 & 2.51 & 1.87 & 1.96 & 4.55 & 1.50 & 2.42 & 2.88 & 0.61 & 11 & 5 & 6 & 94 & 3 & 10 & 17 \\
\hline SDp2A & 2.44 & 2.21 & 1.97 & 4.55 & 2.10 & 2.62 & 2.62 & 0.40 & 11 & 8 & 6 & 94 & 7 & 13 & 13 \\
\hline SP228 & 2.40 & 1.93 & 1.43 & 4.55 & 2.00 & 2.52 & 2.71 & 0.41 & 10 & 6 & 3 & 94 & 6 & 11 & 14 \\
\hline SQ18 & 2.30 & 2.82 & 3.69 & 4.55 & 1.86 & 2.51 & 2.88 & 0.78 & 9 & 16 & 39 & 94 & 5 & 11 & 17 \\
\hline SU80-1 & 2.87 & 2.76 & 2.59 & 4.55 & 2.57 & 2.76 & 3.33 & 0.45 & 17 & 15 & 12 & 94 & 12 & 15 & 27 \\
\hline TBA76125 & 1.61 & 1.89 & 1.00 & 4.55 & 1.33 & 2.08 & 2.59 & 0.50 & 4 & 6 & 2 & 94 & 3 & 7 & 12 \\
\hline TIE84 & 2.58 & 2.69 & 2.69 & 4.55 & 2.08 & 2.55 & 3.21 & 0.70 & 12 & 14 & 14 & 94 & 7 & 12 & 24 \\
\hline TrTrf & 3.40 & 2.85 & 3.87 & 4.55 & 2.48 & 3.23 & 3.02 & 0.69 & 29 & 16 & 47 & 94 & 11 & 24 & 19 \\
\hline Va46 & 2.22 & 3.04 & 3.24 & 4.55 & 2.04 & 2.46 & 2.94 & 0.62 & 8 & 20 & 24 & 94 & 7 & 11 & 18 \\
\hline W438 & 2.16 & 1.97 & 2.08 & 4.55 & 1.61 & 2.13 & 2.42 & 0.50 & 8 & 6 & 7 & 94 & 4 & 7 & 10 \\
\hline W627C & 2.31 & 2.75 & 1.87 & 4.55 & 2.04 & 2.88 & 3.18 & 0.60 & 9 & 15 & 6 & 94 & 7 & 17 & 23 \\
\hline Y5 & 3.05 & 2.85 & 2.79 & 4.55 & 2.13 & 3.20 & 3.67 & 0.58 & 20 & 16 & 15 & 94 & 7 & 24 & 38 \\
\hline A188 & 2.50 & $\ldots$ & 1.87 & 4.55 & 1.97 & 2.55 & 3.61 & 1.64 & 11 & $\ldots$ & 5 & 94 & 6 & 12 & 36 \\
\hline CG1 & 1.51 & $\ldots$ & 0.92 & 4.55 & 1.05 & 1.76 & 2.30 & 1.22 & 4 & $\ldots$ & 2 & 94 & 2 & 5 & 9 \\
\hline
\end{tabular}

${ }^{a} P_{1}=$ the seed parent of the $F_{1}$ cross. $P_{2}=$ inbred FR1064. $F_{1}=$ the cross of $P_{1}$ and $P_{2} . F_{2}$ and backcross to the susceptible parent $\left(B C P_{2}\right)$ generations were developed by self-pollinating $\mathrm{F}_{1}$ plants and by crossing $\mathrm{F}_{1}$ plants with FR1064 as the pollen parent, respectively. A progeny group includes four generations ( $\mathrm{P}_{1}$, $\mathrm{F}_{1}, \mathrm{~F}_{2}$, and $\mathrm{BCP}_{2}$ ) associated with 1 of 35 inbreds selected as $\mathrm{F}_{1}$ hybrids with FR1064 in 2000 .... Indicates not evaluated due to poor emergence or lack of field space.

${ }^{\mathrm{b}}$ Data were transformed to the natural log of the quantity [ $1+$ (micrograms of fumonisin per gram of ground corn)] prior to analyses.

${ }^{c}$ Values presented are geometric means [(antilogarithm of logarithmic means) - 1].

d Fisher's protected least significant difference test.

TABLE 3. Concentration of fumonisin in grain averaged over 35 progeny groups or severity of Fusarium ear and kernel rot averaged over two locations and 35 progeny groups for four generations evaluated in $2001^{\mathrm{a}}$

\begin{tabular}{|c|c|c|c|c|c|c|}
\hline \multirow{3}{*}{$\begin{array}{l}\text { Generation averaged } \\
\text { across progeny groups }{ }^{b}\end{array}$} & \multicolumn{3}{|c|}{ Natural $\log ^{\mathrm{c}}$} & \multicolumn{3}{|c|}{ Antilogarithm ${ }^{\mathrm{d}}$} \\
\hline & \multicolumn{2}{|c|}{$\begin{array}{l}\text { Concentration } \\
\text { of fumonisin in grain }\end{array}$} & \multirow{2}{*}{$\begin{array}{c}\text { Severity } \\
\text { of Fusarium ear rot }\end{array}$} & \multicolumn{2}{|c|}{$\begin{array}{l}\text { Micrograms of fumonisin } \\
\text { per gram of ground corn }\end{array}$} & \multirow{2}{*}{$\begin{array}{c}\begin{array}{c}\text { Percentage of the ear } \\
\text { with symptoms of ear rot }\end{array} \\
\text { Two location average }\end{array}$} \\
\hline & Illinois & Indiana & & Illinois & Indiana & \\
\hline$P_{1}$ & 2.09 & 2.50 & 2.25 & 7 & 11 & 8 \\
\hline $\mathrm{F}_{1}$ & 1.88 & 2.26 & 1.54 & 6 & 9 & 4 \\
\hline $\mathrm{F}_{2}$ & 2.66 & 2.76 & 2.26 & 13 & 15 & 9 \\
\hline $\mathrm{BCP}_{2}$ & 3.26 & 2.86 & 2.22 & 25 & 16 & 8 \\
\hline
\end{tabular}

${ }^{a}$ A progeny group includes four generations associated with 35 genotypes selected in 2000.

${ }^{b} \mathrm{P}_{1}=$ seed parents of $\mathrm{F}_{1}$ crosses. $\mathrm{F}_{1}=$ crosses of seed parents and FR1064. $\mathrm{F}_{2}$ and backcross to the susceptible parent $\left(\mathrm{BCP}_{2}\right)$ generations were developed by selfpollinating $\mathrm{F}_{1}$ plants and by crossing $\mathrm{F}_{1}$ plants with FR1064 as the pollen parent, respectively. By comparison, fumonisin and ear rot severity averaged $94 \mu \mathrm{g} / \mathrm{g}$ and $25 \%$ across locations for the susceptible parent, FR1064.

${ }^{\mathrm{c}}$ Data were transformed to the natural log of the quantity $[1+($ micrograms of fumonisin per gram of ground corn) $]$ or the quantity $[1+($ percentage of the ear with symptoms of ear rot)] prior to analyses.

${ }^{\mathrm{d}}$ Values presented are geometric means [(antilogarithm of logarithmic means) - 1].

${ }^{\mathrm{e}}$ Fisher's protected least significant difference test. 
from four of the selected inbreds, and 8 to $58 \mu \mathrm{g} / \mathrm{g}$ greater in grain from eight of the selected inbreds than from their $\mathrm{F}_{1}$ hybrids with FR1064 when differences between treatment means were averaged over locations. Three of the selected inbreds (M162W, TIE84, and W438) had fumonisin concentration that was not significantly different from their $\mathrm{F}_{1}$ hybrids with FR1064 or their $\mathrm{BCP}_{2}$ generation developed with FR1064.

Treatment means for severity of Fusarium ear and kernel rot ranged from 0 to $40 \%$ with a grand mean of $9 \%$ in Illinois, and from 0 to $37 \%$ with a grand mean of $11 \%$ in Indiana. Severity of Fusarium ear and kernel rot averaged $30 \%$ in Illinois and $21 \%$ in Indiana for the susceptible inbred, FR1064. Severity of Fusarium ear and kernel rot was affected significantly by progeny groups, generations, progeny group-generation, and location-progeny group-generation interactions $(P=0.0061, P=0.0214, P<$ 0.0001 , and $P=0.0004$, respectively). Ear rot severity was not affected significantly by locations or the location-progeny group and location-generation interactions $(P=0.2924, P=0.5126$, and $P=0.3247$, respectively).

Severity of Fusarium ear and kernel rot was lowest for the progeny group developed from inbred GE440 (treatment mean $=$ $2 \%$ ) (Tables 4 and 5). Ear rot severity was not significantly different between progeny group GE440 and two other groups, CG1 and TBA76125. By comparison, ear rot severity was greatest for the progeny group developed from $\operatorname{Tr} \operatorname{Trf}$ (treatment mean $=12 \%$ ) (Tables 4 and 5). Nine other progeny groups had severity of Fusarium ear and kernel rot that was not significantly different than progeny group TrTrf.

Ear rot severity averaged over progeny groups and locations was significantly lower for the $F_{1}$ generation than for the $P_{1}, F_{2}$, and $\mathrm{BCP}_{2}$ generations (Table 3 ). Ear rot severity was not significantly different between the $\mathrm{P}_{1}, \mathrm{~F}_{2}$, and $\mathrm{BCP}_{2}$ generations when data were averaged over progeny groups and locations. Ear rot severity was $4 \%$ for the average of the $\mathrm{F}_{1}$ generations across locations and 8 to $9 \%$ for the average of the $\mathrm{P}_{1}, \mathrm{~F}_{2}$, and $\mathrm{BCP}_{2}$ generations. Ear rot severity of the $\mathrm{F}_{2}$ and $\mathrm{BCP}_{2}$ generations had homogeneous variance with ear rot severity of the $\mathrm{P}_{1}, \mathrm{P}_{2}$, and $\mathrm{F}_{1}$ generations of all progeny groups $(P>0.05)$.

Severity of Fusarium ear and kernel rot was significantly different among progeny groups for the $\mathrm{P}_{1}, \mathrm{~F}_{1}$, and $\mathrm{F}_{2}$ generations in Illinois $(P<0.0001, P=0.0075$, and $P=0.0008$, respectively) and Indiana $(P<0.0001, P=0.0035$, and $P=0.0071$, respectively). Ear rot severity was significantly different among progeny groups for the $\mathrm{BCP}_{2}$ generation in Illinois but not in Indiana $(P<$ 0.0001 and $P=0.2580$, respectively).

Ear rot severity in the $\mathrm{P}_{1}$ generation was lowest for inbred CG1 (treatment mean $=1 \%$ ) in Illinois and inbred GE440 (treatment mean $=0 \%$ ) in Indiana (Tables 4 and 5). Nine inbreds in Illinois

TABLE 4. Natural log of the severity of Fusarium ear and kernel rot for the $\mathrm{P}_{1}, \mathrm{P}_{2}, \mathrm{~F}_{1}, \mathrm{~F}_{2}$, and $\mathrm{BCP}_{2}$ generations associated with 35 progeny groups evaluated in $2001^{\mathrm{a}}$

\begin{tabular}{|c|c|c|c|c|c|c|c|c|c|c|c|c|c|}
\hline \multirow[b]{3}{*}{ Inbred } & \multirow{3}{*}{$\begin{array}{c}\text { Average of } \\
\text { progeny group } \\
\text { across two locations }\end{array}$} & \multicolumn{12}{|c|}{ Average of generation within location ${ }^{\mathrm{b}}$} \\
\hline & & \multicolumn{6}{|c|}{ Illinois } & \multicolumn{6}{|c|}{ Indiana } \\
\hline & & $\mathrm{P}_{1}$ & $\mathrm{P}_{2}$ & $\mathrm{~F}_{1}$ & $\mathrm{~F}_{2}$ & $\mathrm{BCP}_{2}$ & $\operatorname{LSD}_{\alpha=0.05}$ & $\mathrm{P}_{1}$ & $\mathrm{P}_{2}$ & $\mathrm{~F}_{1}$ & $\mathrm{~F}_{2}$ & $\mathrm{BCP}_{2}$ & $\operatorname{LSD}_{\alpha=0.05}$ \\
\hline A635rpld & 2.03 & 1.52 & 3.43 & 0.96 & 1.57 & 1.87 & 0.95 & 2.61 & 3.09 & 1.88 & 3.05 & 2.81 & 1.45 \\
\hline B8 & 2.02 & 2.53 & 3.43 & 1.32 & 2.10 & 1.80 & 1.24 & 3.25 & 3.09 & 1.46 & 1.76 & 1.94 & 1.69 \\
\hline B66 & 1.76 & 0.53 & 3.43 & 1.49 & 1.72 & 1.45 & 0.93 & 2.45 & 3.09 & 1.73 & 2.49 & 2.24 & n.s. \\
\hline BC555 & 2.43 & 3.20 & 3.43 & 1.84 & 2.42 & 2.13 & 0.81 & 3.35 & 3.09 & 1.33 & 2.87 & 2.51 & 1.45 \\
\hline FR36 & 2.01 & 2.46 & 3.43 & 0.62 & 2.27 & 1.78 & 0.79 & 3.10 & 3.09 & 1.25 & 2.35 & 2.28 & 1.20 \\
\hline FR2114 & 1.88 & 1.02 & 3.43 & 1.95 & 2.14 & 3.00 & 0.69 & 1.74 & 3.09 & 1.21 & 2.07 & 2.13 & 0.99 \\
\hline GE440 & 1.23 & & 3.43 & 0.46 & 1.86 & 2.28 & 1.01 & 0.00 & 3.09 & 0.88 & 1.20 & 1.94 & 1.08 \\
\hline H117 & 1.99 & 3.03 & 3.43 & 0.98 & 1.92 & 1.87 & 0.64 & 3.14 & 3.09 & 0.85 & 1.81 & 2.56 & 1.29 \\
\hline J2705TV & 2.33 & $\ldots$ & 3.43 & 1.31 & 2.83 & 2.71 & 0.52 & $\ldots$ & 3.09 & $\ldots$ & 2.63 & 2.52 & 0.81 \\
\hline L289 & 2.01 & 2.41 & 3.43 & 0.93 & 2.21 & 2.41 & 1.21 & 2.31 & 3.09 & 1.48 & 2.09 & 2.21 & 0.58 \\
\hline M14 & 2.11 & 2.35 & 3.43 & 1.56 & 1.83 & 2.16 & 0.84 & $\ldots$ & 3.09 & 3.06 & 2.23 & 2.44 & n.s. \\
\hline SP228 & 2.09 & 1.37 & 3.43 & 1.55 & 2.68 & 2.75 & 0.49 & 1.77 & 3.09 & 2.33 & 2.26 & 2.14 & 1.01 \\
\hline SQ18 & 1.89 & 3.43 & 3.43 & 1.30 & 1.86 & 2.00 & 0.78 & 2.66 & 3.09 & 1.03 & 2.00 & 1.92 & 1.36 \\
\hline SU80-1 & 2.17 & 1.92 & 3.43 & 2.44 & 2.20 & 2.79 & 1.06 & 1.44 & 3.09 & 2.14 & 2.32 & 2.21 & n.s. \\
\hline TBA76125 & 1.50 & 1.85 & 3.43 & 1.06 & 1.70 & 1.47 & 0.60 & 2.20 & 3.09 & 0.65 & 1.70 & 1.52 & 1.33 \\
\hline TIE84 & 2.37 & 3.18 & 3.43 & 1.59 & 2.21 & 2.22 & 1.45 & 3.59 & 3.09 & 1.75 & 2.24 & 2.21 & 0.87 \\
\hline TrTrf & 2.59 & 3.69 & 3.43 & 1.89 & 3.07 & 2.31 & 0.86 & 3.61 & 3.09 & 1.81 & 2.57 & 2.32 & n.s. \\
\hline Va46 & 2.09 & 2.19 & 3.43 & 0.85 & 1.84 & 2.32 & 0.96 & 2.62 & 3.09 & 1.82 & 2.72 & 2.58 & n.s. \\
\hline W438 & 1.79 & 0.84 & 3.43 & 1.64 & 2.19 & 2.10 & 1.11 & 2.74 & 3.09 & 0.64 & 2.17 & 1.79 & n.s. \\
\hline W627C & 2.31 & 2.89 & 3.43 & 1.15 & 2.37 & 2.35 & 0.54 & 3.44 & 3.09 & 2.13 & 2.49 & 1.73 & n.s. \\
\hline Y5 & 2.19 & 2.88 & 3.43 & 0.92 & 2.59 & 2.56 & 1.15 & 1.87 & 3.09 & 1.90 & 2.23 & 2.58 & 0.71 \\
\hline A188 & 2.17 & 1.87 & 3.43 & 1.85 & 1.95 & 2.99 & 1.83 & $\ldots$ & $\ldots$ & $\ldots$ & $\ldots$ & $\ldots$ & $\ldots$ \\
\hline CG1 & 1.40 & 0.50 & 3.43 & 0.56 & 2.53 & 2.02 & 1.56 & $\ldots$ & $\ldots$ & $\ldots$ & $\ldots$ & $\ldots$ & $\ldots$ \\
\hline CK31 & 2.16 & 1.12 & 3.43 & 1.89 & 3.29 & 2.32 & 1.73 & $\ldots$ & $\ldots$ & $\ldots$ & $\ldots$ & $\ldots$ & $\ldots$ \\
\hline
\end{tabular}

${ }^{a}$ Data were transformed to the natural $\log$ of the quantity $(1+$ percentage of the ear with symptoms $)$ prior to analysis. $P_{1}=$ the seed parent of the $F_{1}$ cross. $\mathrm{P}_{2}=$ inbred FR1064. $F_{1}=$ the cross of $P_{1}$ and $P_{2} . F_{2}$ and backcross to the susceptible parent $\left(B_{C}\right)$ generations were developed by self-pollinating $F_{1}$ plants and by crossing $\mathrm{F}_{1}$ plants with FR1064 as the pollen parent, respectively. A progeny group includes four generations associated with 1 of 35 inbreds selected based on $\mathrm{F}_{1}$ performance in 2000 .

${ }^{\mathrm{b}}$ LSD $=$ Fisher's protected least significant difference test. n.s. = not significant. ... Indicates not evaluated due to poor emergence or lack of field space. 
had ear rot severity that was not significantly different from inbred CG1. Ear rot severity in the $\mathrm{F}_{1}$ generation was lowest for the hybrid GE440 $\times$ FR1064 (treatment mean $=1 \%$ ) in Illinois and $\mathrm{W} 438 \times$ FR1064 (treatment mean $=1 \%$ ) in Indiana. Nineteen $F_{1}$ hybrids in Illinois and $15 \mathrm{~F}_{1}$ hybrids in Indiana had ear rot severity that was not significantly different from $F_{1}$ hybrids GE440 $\times$ FR1064 and W438 × FR1064, respectively. Ear rot severity in the $\mathrm{F}_{2}$ generation was lowest for the $\mathrm{F}_{2}$ developed from A635rpld (treatment mean $=4 \%$ ) in Illinois and GE440 (treatment mean $=$ $2 \%$ ) in Indiana. $\mathrm{F}_{2}$ generations from 20 progeny groups in Illinois and 7 progeny groups in Indiana had ear rot severity that was not significantly different from the $F_{2}$ generations developed from inbreds A635rpld and GE440, respectively. Ear rot severity in the $\mathrm{BCP}_{2}$ generation was lowest for the $\mathrm{BCP}_{2}$ developed from inbred TBA76125 in Illinois (treatment mean $=3 \%$ ). $\mathrm{BCP}_{2}$ generations from 12 progeny groups in Illinois had ear rot severity that was not significantly different from the $\mathrm{BCP}_{2}$ developed from inbred TBA76125.

Of seven possible generation $\times$ location combinations $\left(\mathrm{P}_{1}, \mathrm{~F}_{1}\right.$, $\mathrm{F}_{2}$, and $\mathrm{BCP}_{2}$ in Illinois and $\mathrm{P}_{1}, \mathrm{~F}_{1}$, and $\mathrm{F}_{2}$ in Indiana), progeny groups B66, CQ201, SQ18, and TBA76125 each had six combinations that were not significantly different from generations with the lowest severity of Fusarium ear and kernel rot (Tables 4 and 5 ). Five generation $\times$ location combinations from progeny groups A635rpld, B8, and H117, and four combinations from progeny groups FR2114, FR36, GE440, M162W, and Va46 were not sig- nificantly different from generations with the lowest severity of Fusarium ear and kernel rot.

Severity of Fusarium ear and kernel rot was significantly different between FR1064 and the selected inbreds from progeny groups CM5, FR2114, and Sp228 in both locations (Tables 4 and 5). Ear rot severity was significantly different between FR1064 and 13 other selected inbreds in Illinois only (A635rpld, B66, CQ201, FR36, M14, RN28Htrhm, SDp2A, SU80-1, TBA76125, Va46, W438, CG1, and CK31) and four other selected inbreds in Indiana only (A131, GE440, L289, and Y5).

Severity of Fusarium ear and kernel rot was significantly different between nine of the selected inbreds (BC555, CM5, FR36, H117, L289, SDp2A, SQ18, TBA76125, and TIE84) and their $F_{1}$ hybrids with FR1064 in both locations (Tables 4 and 5). Ear rot severity was greater for eight of the inbreds (BC555, FR36, H117, L289, SDp2A, SQ18, TBA76125, and TIE84) than for their $F_{1}$ hybrids in both locations. Ear rot severity was lower for one of the inbreds (CM5) than its $\mathrm{F}_{1}$ hybrid in both locations.

\section{DISCUSSION}

Several inbreds were identified with a high level of resistance to the production or accumulation of fumonisin in grain. These inbreds were highly resistant when evaluated as inbreds per se and when evaluated in combination with FR1064 as the $F_{1}, F_{2}$, and $\mathrm{BCP}_{2}$ generations. Alleles for resistance from these inbreds

TABLE 5. Antilogarithm of natural log-transformed severity of Fusarium ear and kernel rot for the $\mathrm{P}_{1}, \mathrm{P}_{2}, \mathrm{~F}_{1}, \mathrm{~F}_{2}$, and $\mathrm{BCP}_{2}$ generations associated with 35 progeny groups evaluated in $2001^{\mathrm{a}}$

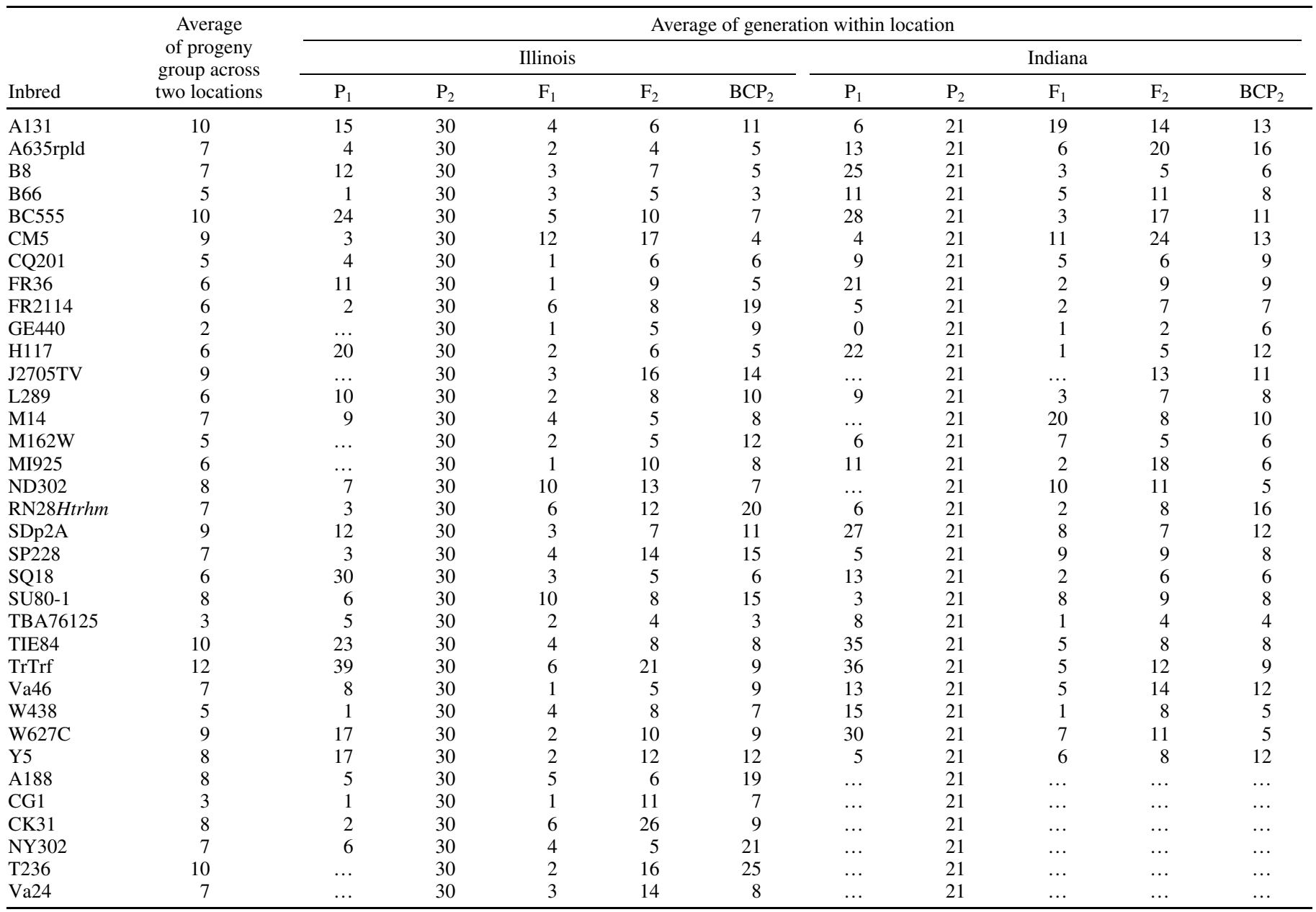

${ }^{a}$ Values presented are geometric means [(antilogarithm of logarithmic means) -1$] . P_{1}=$ the seed parent of the $F_{1}$ cross. $P_{2}=$ inbred FR1064. $F_{1}=$ the cross of $P_{1}$ and $\mathrm{P}_{2} . \mathrm{F}_{2}$ and backcross to the susceptible parent $\left(\mathrm{BCP}_{2}\right)$ generations were developed by self-pollinating $\mathrm{F}_{1}$ plants and by crossing $\mathrm{F}_{1}$ plants with $\mathrm{FR} 1064$ as the pollen parent, respectively. A progeny group includes four generations associated with 1 of 35 inbreds selected based on $F_{1}$ performance in 2000 .... Indicates not evaluated due to poor emergence or lack of field space. 
appear to be dominant in crosses with FR1064, because the resistant inbred parents and their $\mathrm{F}_{1}$ hybrids with FR1064 often had a comparable fumonisin concentration in grain. Overdominance or less significant alleles from FR1064 also may be involved in resistance because some of the $\mathrm{F}_{1}$ hybrids were more resistant than either of the parental lines. The $\mathrm{F}_{2}$ and $\mathrm{BCP}_{2}$ generations developed from many of the inbreds are highly resistant, suggesting that plants within these generations express little phenotypic segregation for resistance and susceptibility and that several genes are likely involved in resistance. These results expand on the work of other researchers who determined that silk-mediated resistance to kernel infection by $F$. verticillioides is dominant $(20,41)$ and that several effective factors are involved in resistance to kernel infection by $F$. verticillioides (33).

Unlike fumonisin concentration in grain, severity of Fusarium ear and kernel rot was generally low, and the range of treatment means for ear rot was narrow in the experiment of 2001. Fusarium ear and kernel rot was generally less severe for $F_{1}$ hybrids than for either of the parental lines, the $\mathrm{F}_{2}$ generation, and the $\mathrm{BCP}_{2}$ generation; however, differences between generations were not great enough to draw valid conclusions about the type of gene action involved in resistance to ear rot.

The majority of inbred seed parents developed for commercial hybrid production in the United States have been derived from Stiff Stalk Synthetic or other related Reid Yellow Dent "types" such as the inbred B73 $(18,48)$. FR1064 was selected as the "susceptible" parent in these experiments because it is a commercial "B73-type" line that has been developed for hybrid production throughout the Midwest. Like many similar lines, FR1064 is not especially susceptible to Fusarium ear and kernel rot. Other more susceptible inbreds could have been chosen as the "susceptible" parent in this study; however, these inbreds are not marketed commercially. Information from studies using noncommercial inbreds would be less valuable in pragmatic breeding programs aimed at improving hybrids grown in the United States.

Because FR1064 is similar to other B73-type commercial inbreds, alleles from inbreds identified in this study that improve the resistance of FR1064 could improve the resistance of a large number of lines used to produce commercial hybrids in the United States. Many of the $F_{1}$ hybrids evaluated in 2000 had a concentration of fumonisin in grain that was slightly greater than $5 \mu \mathrm{g} / \mathrm{g}$ in both Illinois and North Carolina. Some of the inbreds used to produce these crosses may have novel genes that contribute to the resistance of FR1064 and other B73-type lines.

The 35 inbreds used to produce generations evaluated in 2001 form a genetically diverse group, including lines with yellow, white or red kernels; lines with flint- or dent-type kernels; lines with early maturity developed in Canada, eastern Europe, or the northern United States; and lines with moderate to late maturity developed in western Europe, the central United States, the southern United States, or Mexico. Although $\mathrm{F}_{1}$ hybrids of these lines with FR1064 had a low fumonisin concentration in grain, $F_{1}$ hybrids produced with some of the inbred parents from which these lines were derived had a fumonisin concentration in grain near or greater than $20 \mu \mathrm{g} / \mathrm{g}$. This was especially apparent with inbreds released from Virginia (Va24 and Va46), for which fumonisin concentration in grain was between 5 and $20 \mu \mathrm{g} / \mathrm{g}$ from the $\mathrm{F}_{1}$ cross of one progenitor line (Va17), and greater than $20 \mu \mathrm{g} / \mathrm{g}$ from $\mathrm{F}_{1}$ crosses of three progenitor lines (Va36, T8, and Wf9) in 2000 (12). This suggests that unique combinations of genes are involved in resistance to fumonisin production or accumulation in grain for some of the inbreds identified in this study.

Several of the inbreds used to produce the generations evaluated in 2001 were developed in the northern United States and Canada (e.g., A131, A635rpld, CG1, CK31, CM5, and CQ201, and ND302). Although ears on all plants were inoculated according to their developmental stage (R1 and R2) in 2000 and 2001, early maturity could have an effect on minimizing fumonisin concentration in grain of some genotypes. The earliest maturing inbreds and their $F_{1}$ hybrids typically flowered about 10 days prior to the mean flowering date (approximately 100 days after planting) of the experiment in 2001. Data on physiological maturity, rate of kernel fill, and the effective grain filling period were not collected in this study. Disease may be minimized on ears of early-maturing inbreds and hybrids if kernels mature quickly and kernel moisture drops rapidly below levels that are favorable for growth and sporulation of Fusarium spp. $(21,26,28)$.

A number of inbreds (e.g., J2705TV and M14) flowered approximately 20 days later than the earliest maturing inbreds in 2001. $F_{1}$ hybrids produced with these later-maturing inbreds were highly or moderately resistant to fumonisin accumulation in grain and Fusarium ear and kernel rot. Flowering dates of $F_{1}$ hybrids produced with later-maturing inbreds typically were comparable to the mean flowering date of the experiment in 2001. As with earlier-maturing inbreds and their $\mathrm{F}_{1}$ hybrids, later-maturing inbreds and their $F_{1}$ hybrids were inoculated according to their developmental stage. Therefore, factors other than flowering date (e.g., rapid kernel development, low kernel moisture, or distinct kernel proteins) serve an important function in resistance to fumonisin production and accumulation in grain and possibly in resistance to Fusarium ear and kernel rot.

Ear rot severity was low (less than 5\%) and fumonisin concentration in grain was at a level of concern $(>20 \mu \mathrm{g} / \mathrm{g})$ for roughly 6 and $3 \%$ of the hybrids evaluated in 2000 in Illinois and North Carolina, respectively. This is not unexpected, because isolates chosen for this study were selected primarily on their capacity to synthesize fumonisin in corn grain. This agrees with observations made by other researchers who detected fumonisin at levels of concern in apparently healthy corn kernels $(4,11,34,35,39)$ and emphasizes the need to select for resistance to both fumonisin in grain and ear rot in corn breeding programs.

Several of the inbreds evaluated in this study have been associated with resistance to Aspergillus ear rot and resistance to the production or accumulation of aflatoxin in grain $(5,6,19)$. Typically, crosses of these inbreds (e.g., LB31, OH513, OH516, Tex6, and others) with the Stiff Stalk Synthetic-derived inbred B73, or the Lancaster Surecrop-derived inbred Mo17, produced $F_{1}$ hybrids with a low aflatoxin concentration in grain and a low severity of Aspergillus ear rot when kernel wounding was a component of the inoculation process (6). $F_{1}$ hybrids produced from crosses of these inbreds with FR1064 were moderately to highly susceptible to Fusarium ear and kernel rot and the production and accumulation of fumonisin in grain. Specific proteins or other kernel components are likely involved in resistance to Aspergillus ear rot and the accumulation of aflatoxin in grain that are not involved in resistance to Fusarium ear and kernel rot and the accumulation of fumonisin in grain.

Researchers studying Aspergillus ear rot and the accumulation of aflatoxin in grain have reported difficulties in determining the gene action associated with resistance and in transferring alleles for resistance into agronomically favorable backgrounds. Often, difficulties arise from environmental effects on a selected inbred, in that differences between resistant and susceptible parents become obscured during conditions when disease and mycotoxin production are favored $(29,49)$. Typically, the resistant inbreds chosen for these studies $(29,49)$ were selected by evaluating the performance of the $\mathrm{F}_{1}$ hybrid, but not by evaluating the performance of the inbreds.

We hoped to avoid difficulties encountered in studies of Aspergillus ear rot and aflatoxin by not only evaluating $F_{1}$ hybrids in multiple years and locations, but also by evaluating the parents of the hybrids, and the $\mathrm{F}_{2}$ and $\mathrm{BCP}_{2}$ generations. By doing so, resistance associated with dominant alleles could be selected and the number of inbreds included in other studies could be reduced. 


\section{ACKNOWLEDGMENTS}

This study presents results of research only and is based on work supported by CFAR award IDACF01I-14-3 and by the National Research Institute award AG2001-35201-10060. We thank Monsanto Company (J. Perkins and S. Walker) and Syngenta Seeds, Inc. (D. Kendra) for field space provided during this experiment; and C. Kleinschmidt, L. Maupin, S. Phillips, and S. Sipp for assistance during fieldwork.

\section{LITERATURE CITED}

1. Anderson, B. M., and Dolezal, W. E. 1993. Prevalence and distribution of fumonisin in the United States. Pages 139-149 in: Proc. 48th Annu. Corn and Sorghum Res. Conf. American Seed Trade Assoc., Washington D.C.

2. Boewe, G. H. 1936. The relation of ear rot prevalence in Illinois corn fields to ear coverage by husks. Illinois Nat. Hist. Surv. Biol. Notes No. 6.

3. Boling, M. B., and Grogan, C. O. 1965. Gene action affecting host resistance to Fusarium ear rot of maize. Crop Sci. 5:305-307.

4. Bullerman, L. B., and Tsai, W. J. 1994. Incidence and levels of Fusarium moniliforme, Fusarium proliferatum and fumonisins in corn and cornbased foods and feeds. J. Food Prot. 57:541-546.

5. Campbell, K. W., Hamblin, A. M., and White, D. G. 1997. Inheritance of resistance to aflatoxin production in the cross between corn inbreds B73 and LB31. Phytopathology 87:1144-1147.

6. Campbell, K. W., and White, D. G. 1995. Evaluation of corn genotypes for resistance to Aspergillus ear rot, kernel infection, and aflatoxin production. Plant Dis. 79:1039-1045.

7. Center for Food Safety and Applied Nutrition. 2001. Background paper in support of fumonisin levels in corn and corn products intended for human consumption. Online publication. USFDA Center for Food Safety and Applied Nutrition. Docket No. 00D-1277.

8. Center for Food Safety and Applied Nutrition. 2001. Guidance for industry: Fumonisin levels in human foods and animal feeds. Online publication. USFDA Center for Food Safety and Applied Nutrition and the Center for Veterinary Medicine. Docket No. 00D-1277.

9. Cheng, S. J., Jiang, Y. Z., Li, M. H., and Lo, H. Z. 1985. A mutagenic metabolite produced by Fusarium moniliforme isolated from Linxian County, China. Carcinogenesis 6:903-905.

10. Christensen, J. J., and Schneider, C. L. 1950. European corn borer (Pyrausta nubilalis HBN.) in relation to shank, stalk, and ear rots of corn. Phytopathology 40:284-291.

11. Chu, F. S., and Li, G. Y. 1994. Simultaneous occurrence of fumonisin $B_{1}$ and other mycotoxins in moldy corn collected from the People's Republic of China in regions of high incidences of esophageal cancer. Appl. Environ. Microbiol. 60:847-852.

12. Clements, M. J. 2002. Resistance to fumonisins and Fusarium ear rot of corn. Ph.D. thesis. Department of Crop Sciences, University of Illinois, Urbana.

13. Clements, M. J., Kleinschmidt, C. E., Maragos, C. M., Pataky, J. K., and White, D. G. 2003. Evaluation of inoculation techniques for Fusarium ear rot and fumonisin contamination of corn. Plant Dis. 87:147153.

14. Davis, R. M., Kegel, F. R., Sills, W. M., and Farrar, J. J. 1989. Fusarium ear rot of corn. Calif. Agric. 43:4-5.

15. Desjardins, A. E., and Plattner, R. D. 1998. Distribution of fumonisins in maize ears infected with strains of Fusarium moniliforme that differ in fumonisin production. Plant Dis. 82:953-958.

16. Doko, M. B., and Visconti, A. 1994. Occurrence of fumonisins $B_{1}$ and $B_{2}$ in corn and corn-based human foodstuff in Italy. Food Addit. Contam. 11:433-439.

17. Farrar, J. J., and Davis, R. M. 1991. Relationships among ear morphology, western flower thrips, and Fusarium ear rot of corn. Phytopathology 81:661-666.

18. Gerdes, J. T., Behr, C. F., Coors, J. G., and Tracy, W. F. 1993. Compilation of North American Maize Breeding Germplasm. W. F. Tracy, J. G. Coors, and J. L. Geadelmann, eds. Crop Science Society of America, Madison, WI.

19. Hamblin, A. M., and White, D. G. 2000. Inheritance of resistance to Aspergillus ear rot and aflatoxin production of corn from Tex6. Phytopathology 90:292-296.

20. Headrick, J. M., and Pataky, J. K. 1991. Maternal influence on the resistance of sweet corn lines to kernel infection by Fusarium moniliforme. Phytopathology 81:268-274.

21. Headrick, J. M., Pataky, J. K., and Juvick, J. A. 1990. Relationships among carbohydrate content of kernels, condition of silks after pollination, and the response of sweet corn inbred lines to infection by Fusarium moniliforme. Phytopathology 80:487-494.
22. Hesseltine, C. W., and Bothast, R. J. 1977. Mold development in ears of corn from tasseling to harvest. Mycologia 69:328-340.

23. Hoenisch, R. W., and Davis, R. M. 1994. Relationship between kernel pericarp thickness and susceptibility to Fusarium ear rot in field corn. Plant Dis. 78:517-519.

24. King, S. B., and Scott, G. E. 1981. Genotypic differences in maize to kernel infection by Fusarium moniliforme. Phytopathology 71:12451247.

25. Kleinschmidt, C. E., Pataky, J. K., Maragos, C. M., and White, D. G. 2002. Evaluation of food-grade dent corn hybrids for Fusarium ear rot and fumonisin $\mathrm{B}_{1}$ concentration, 2000. Online Publication. Biological and Cultural Tests for Control of Plant Diseases. Report No. 17:C02. The American Phytopathological Society, St. Paul, MN.

26. Koehler, B. 1938. Fungus growth in shelled corn as affected by moisture. J. Agric. Res. 56:291-307.

27. Koehler, B. 1942. Natural mode of entrance of fungi into corn ears and some symptoms that indicate infection. J. Agric. Res. 64:421442 .

28. Lawrence, E. B., Nelson, P. E., and Ayers, J. E. 1981. Histopathology of sweet corn seed and plants infected with Fusarium moniliforme and Fusarium oxysporum. Phytopathology 71:379-386.

29. Maupin, L. M. 2002. Resistance to aflatoxin production from the MI82 corn line. M.S. thesis. Department of Crop Sciences, University of Illinois, Urbana.

30. Munkvold, G. P., and Desjardins, A. E. 1997. Fumonisins in maize, can we reduce their occurrence? Plant Dis. 81:556-565.

31. Munkvold, G. P., McGee, D. C., and Carlton, W. M. 1997. Importance of different pathways for maize kernel infection by Fusarium moniliforme. Phytopathology 87:209-217.

32. Murphy, P. A., Rice, L. G., and Ross, P. F. 1993. Fumonisin $B_{1}, B_{2}$ and $B_{3}$ content of Iowa, Wisconsin and Illinois corn and corn screenings. J. Agric. Food Chem. 41:263-268.

33. Nankam, C., and Pataky, J. K. 1996. Resistance to kernel infection by Fusarium moniliforme in the sweet corn inbred IL125b. Plant Dis. 80:593-598.

34. Nelson, P. E. 1992. Taxonomy and biology of Fusarium moniliforme. Mycopathologia 117:29-36.

35. Nelson, P. E., Desjardins, A. E., and Plattner, R. D. 1993. Fumonisins, mycotoxins produced by Fusarium species: Biology, chemistry, and significance. Annu. Rev. Phytopathol. 31:233-252.

36. Odvody, G. N., Remmers, J. C., and Spencer, N. M. 1990. Association of kernel splitting with kernel and ear rots of corn in a common hybrid grown in the coastal bend of Texas. Phytopathology 80:1045

37. Ooka, J. J., and Kommedahl, T. 1977. Wind and rain dispersal of Fusarium moniliforme in corn fields. Phytopathology 67:1023-1026.

38. Ott, R. L. 1993. An Introduction to Statistical Methods and Data Analysis. 4th ed. Duxbury Press, Belmont, CA.

39. Rheeder, J. P., Marasas, W. F. O., Thiel, P. G., Sydenham, E. W., Shephard, G. S., and Schalkwyk, D. J. V. 1992. Fusarium moniliforme and fumonisins in corn in relation to human esophageal cancer in Transkei. Phytopathology 82:353-357.

40. Scott, D. H., Grogan, J., Gann, R., Everson, R. J., and Binkerd, K. 1992. Summary of 1989, 1990, and 1991 pre-harvest corn ear rot/mycotoxin survey in Indiana. Purdue Univ. Agric. Exp. Stn. Bull. 645.

41. Scott, G. E., and King, S. B. 1984. Site of action of factors for resistance to Fusarium moniliforme in maize. Plant Dis. 68:804-806.

42. Smeltzer, D. G. 1959. Relationship between Fusarium ear rot and corn earworm infestation. Agron. J. 51:53-54.

43. Smith, F. L., and Madsen, C. 1949. Susceptibility of inbred lines of corn to Fusarium ear rot. Agron. J. 41:347-348.

44. Sobek, E. A., and Munkvold, G. P. 1999. European corn borer (Lepidoptera: Pyralidae) larvae as vectors of Fusarium moniliforme, causing kernel rot and symptomless infection of maize kernels. J. Econ. Entomol. 92:503-509.

45. Stack, M. E. 1998. Analysis of fumonisin $B_{1}$ and its hydrolysis product in tortillas. J. AOAC Int. 81:737-740.

46. Styer, R. C., and Cantliffe, D. J. 1984. Infection of two endosperm mutants of sweet corn by Fusarium moniliforme and its effects on seedling vigor. Phytopathology 74:189-194.

47. Sydenham, E. W., Thiel, P. G., Marasas, W. F. O., Shephard, G. S., Schalkwyk, D. J. V., and Koch, K. R. 1990. Natural occurrence of some Fusarium mycotoxins in corn from low and high esophageal cancer prevalence areas of the Transkei, South Africa. J. Agric. Food Chem. 38:1900-1903.

48. Troyer, A. F. 1999. Background of U.S. hybrid corn. Crop Sci. 39:601626.

49. Walker, R. D., and White, D. G. 2001. Inheritance of resistance to Aspergillus ear rot and aflatoxin production of corn from CI2. Plant Dis. $85: 322-327$ 
50. Warfield, C. Y., and Davis, R. M. 1996. Importance of the husk covering on the susceptibility of corn hybrids to Fusarium ear rot. Plant Dis. 80:208-210.

51. Warren, H. L. 1978. Comparison of normal and high-lysine maize inbreds for resistance to kernel rot caused by Fusarium moniliforme. Phytopathology 68:1331-1335.

52. Windels, C. E., Windels, M. B., and Kommedahl, T. 1976. Association of Fusarium species with picnic beetles on corn ears. Phytopathology
66:328-331.

53. Woloshuk, C. P., Gann, R., and Everson, R. J. 2001. Fusarium ear rot and fumonisin contamination: An Indiana survey 1991-2001. Page 57 in: Proc. 1st Fungal Genomics, 2nd Fumonisin Elimination and 14th Aflatoxin Elimination Workshop, Phoenix, AZ.

54. Zummo, N., and Scott, G. E. 1990. Cob and kernel infection by Aspergillus flavus and Fusarium moniliforme in inoculated field-grown maize ears. Plant Dis. 74:627-631. 